\title{
ПИТАННЯ ТЕОРЕТИЧНІ
}

DOI: $10.33608 / 0236-1477.2020 .06 .3-30$

УАК 82.091

Юрій БАРАБАШ, Аоктор філологічних наук, професор Інститут світової нітератури ім. О. М. Горького Російської академії наук ум. Поварская, 25а, Москва, 121069 e-mail: barabash.yuri@gmail.com ORCID: https://orcid.org/0000-0002-8938-9408

\section{ЧУЖЕ-ІНАКШЕ-СВОЕ. ПІВНІЧНО- СХIАНЕ ЕТНО- Й АІНГВОКУАЬТУРНЕ ПОГРАНИЧЧЯ УКРАЇНИ (Харків. Аонбас)}

\section{Стаття Аруга ${ }^{1}$}

Стаття містить розгляд фактів і проблематики, що стосуються етно- й лінгвокультурного пограничия на Північному Сході України. Проведено діахронічний аналіз основних етапів літературного прочесу на Слобожсншині, передовсіму ї центрі, Харкові («Харківський сетмент»), схарактеризовано роль заснованого 1805 року Харківського університету, харківських російсько- й українськомовних періодичних видань і збірників, діяльності таких ключових постатей регіону, як Г. Сковорода, Г. Квітка-Основ'яненко, П. Гулак-Артемовський, I. Срезневський, М. Костомаров, О. Потебня та ін., особливостей літературного життл Харкова в добу національного культурного відродження 20-x - початку 30-х рр. і в наступні періоди до останніх років включно. Аналіз етно- йлінтвокультурної роблематики в «донбаському сетменті» провадиться в синхронічному зрізі, у компаративному зіставленні різних письменницьких доль і творчих феноменів, і то на тлі сучасних драматичних подій у цьому регіоні України.

Ключовіслова: пограниччя, харківський сегмент, поліетнічність, ідентичність, лінгвокультурна ситуачія, Харківська школа романтиків, «Розстріляне відродження», шістдесятництво, донбаський сегмент.

\footnotetext{
${ }^{1}$ Статтю першу «Чуже-Інакше-Своє. Етнокультурне пограниччя: концептуальний, типологічний та ситуативний аспекти» Аив. у: Слово і Час, 2020, № 2.
}

Цитування: Барабаш Юрій. Чуже-Інакше-Своє. Північно-східне етно- й мінгвокультурне пограниччя України (Харків. Аонбас). Слово і Час. 2020. № 6 (714). С. 3-30. https://doi.org/10.33608/0236-1477.2020.06.3-30 


\section{Харківський сетмент}

Знаменитий вірш Тичини «Харків, Харків, де твоє обличчя?» (1923) - своєрідна поетична модемь концепту пограниччя. Маємо випадок психологічного переходу від першого, у певному сенсі стресового,

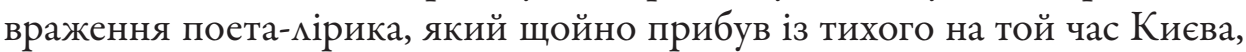
зберігаючи живу пам'ять про провінційний, але прекрасний Чернігів, до сприйняття Харкова - індустріальної столиці-мегаполіса з притаманними їй різкими соціальними та культурними контрастами, з фронтирними зонами між Університетською гіркою і старими ремісничими вулицями Чоботарською, Коцарською, Кузнечною, між елітарним «нагорним районом» і біАними, зчаста кримінальними, околицями, між значно зрусифікованою промисловою Петінкою і оспіваними КвіткоюОснов'яненком Гончарівкою та Основою, які ще не зовсім утратили національні прикмети. Між пролетарським духом і «міщанським душком», як тоді говорили.

Концепт пограниччя був закорінений в історичній долі Слобожанщини та ії центру - Харкова. Ця, за виразом Франка, «харківська Україна», від самого початку скцадалася як поліетнічний регіон - із переважно українським, почасти російським головно міським, торговельно-ремісничим населенням; етнічні росіяни складали частину слобожанського дворянства, втім, Аворянства набували, з волі монархині, також представники української старшини. Саме поліетнічність слобожанського соціуму була провідним чинником, що визначив характер i особливості розвитку етнокультурної ситуації в краї, передовсім у Харкові (див.: [14; 21]).

Ауже важливим чинником формування слобожанського етнокультурного простору була діяльність «українського Сократа» - Григорія Сковороди, який упродовж десяти років, із перервами, викладав у Харківському колегіумі поетику, синтаксис, етику та грецьку мову. Філософська та Аітературна спадщина Сковороди означила завершення плідної

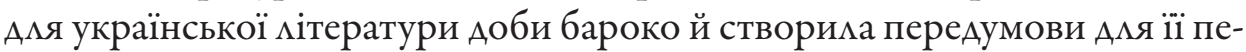
реходу до нового етапу розвитку.

$\Lambda$. Ушкалов слушно зазначав, що «слобідську традицію, так само, як і галицьку, просто несима уявити “поза Європою”». Аیя вихованців Харківського колегіуму, Аля учнів Сковороди, молодих Аюдей його кола був характерний активний інтерес до французького просвітительства й, особливо, до німецької романтичної філософії та містики. Саме віА Сковороди, підкреслює $\Lambda$. Ушкалов, починається «німецький сліА» на Слобожанщині, що бачимо, зокрема, на прикмаді національного складу викцадачів Харківського університету, відкритого 1805 року $[36,4,6]$. Із 47 професорів 18 (19?) були німцями, з-поміж них рекомендовані Гете, на прохання попечитемя харківського навчального округу графа Севери- 
на Потоцького, Й.-Б. ШаА ${ }^{1}$ (він замінив Й.-Г. Фіхте, чий приїзд до Харкова був намічений, але не відбувся через збіг обставин), $\Lambda$. Шнауберт, М. Пільгер, також К. А. Роммель, який згодом описав у мемуарах своє перебування в Харкові (Аив.: [32]), А. Ванноті, Ф. Гізе, Й. Аанг, Б. Райт, К. Нельдехен та ін.

Більшість іноземних викцадачів опановували російську мову, а Роммель навіть українську, проте мекції свої вони читаци головно матинською. Загалом мовою спілкування та навчання була російська. Першим ректором університету був вихованець Псковської духовної семінарії, російський письменник, філолог і філософ Іван Рижський. Російськомовними були започатковані з ініціативи викладачів університету перші на Слобожанщині періодичні видання - газета «Харьковский еженеАельник», журнали «Украинский Вестник», «Украинский журнам», «Харьковский Аемокрит».

Хоча вирисовується досить чітка картина превалювання російської мови в тодішньому харківському науково-культурному, передовсім університетському, просторі, все ж картина постане однобічною без урахування двох чинників. Раз - що українськомовне оточення, домінування української мови в харківському, особливо слобожанському сільському, середовищі було реальним фактом. А саме із цього середовища (це Аруге) виходила значна частина харківського студентства, та й декого з виклаАацького скцаду, тож у коридорах університету мунала українська мова, навіть у мекціях можна було почути українські слова, звороти, інтонації.

В університетському (та близькому до нього) середовищі зароджувалися й дедалі активніше заявлями про себе тенденції та течї, які були пов'язані зі загацьнонаціонацьним процесом становцення нової української мітератури, усвідомлення націонацьною культурною й науковою елітою своєї ідентичності й водночас відбивали специфіку слобожанського (харківського) етно- та Аінгвокультурного пограниччя.

Типовими і кмючовими постатями були в післясковородинському Харкові Григорій Квітка-Основ'яненко та Петро Гулак-Артемовський.

Квітка - корінний слобожанин-харків'янин, він народився у приміській слободі (селі) Основа, у старшинсько-шляхетській родині, де панував культ української мови, історії, культури. Квітка отримав домашню освіту, він не навчався в Харківському університеті, але у зрілі роки був тісно пов'язаний із ним як член університетського Товариства наук й один із найактивніших учасників громадського та культурного життя Харкова.

\footnotetext{
${ }^{1}$ Цей філософ-фіхтеанець вирізнявся вільнодумством й антикмерикалізмом, які до того ж виявляв одверто, за що його зрештою було видворено з Росії, а його книжку «Institutiones juris naturae» («Установи природного права») спалено [Аив.: 4 ].
} 
Перші свої твори Квітка написав російською, це комедії «Приезжий из столицы, или Суматоха в уездном городе» (iї вважають попередницею гоголівського «Ревізора») та «Шемьменко-денщик», а також «Аворянские выборы», високо поціновані С. Аксаковим і М. Полєвим, але не дозволені А^я постановки. Ао історії української мітератури Квітка ввійшов як засновник нової прози та комеАії, створивши цілий корпус повістей бурлескносміхового та сентиментально-реалістичного гатунку «Салдацький патрет», «Пархімове сніАання», «Конотопська відьма», «Маруся», «Сердечна Оксана», «Козир-дівка», комедію «Сватання на Гончарівці», які стали хрестоматійними. Практично паралемьно із цими творами Квітка писав російськомовну прозу - роман «Пан Халявский», повісті «Жизнь и похождения Петра Степанова сына Стомбикова», «Ганнуся», «Панна Сотниковна», історико-етнографічні та фізіологічні нариси. Це була характерна особливість тогочасного культурно-історичного етапу - етапу становлення нової національної мітератури та прикмета слобожанського етнокультурного пограниччя, де російська мова мала значне поширення, передовсім у системі освіти, в культурному житті, в Аітературній творчості; при цьому, однак, мовою широких кіл населення залишалася українська, щоправда, певною мірою позначена слобожанськими суржиковими рисами.

Показові приклади різних форм мовної двоїстості в російськомовних творах Квітки. Це може бути чітке фронтирне розмежування російського і українського мовних шарів. У комедії «Шемьменко-денщик», наприклаА, така фронтирність виконує виразну структурну та соціальну функцію: російською розмовмяють персонажі, які репрезентують привімейований, освічений клас. Це не тільки російський офіщер Скворцов, а й українські поміщики, їхні Аружини й Аіти, котрі намагаються, так би мовити, триматися «на рівні», навіть їхні покоївки та макеї, тоді як українською - лише денщик. Шельменко, щоправда, перемішує свою зіпсовану рідну українську російськими (точніше, такими, що зАаються йому російськими) канцемярськими або «москальськими» слівцями та зворотами, суттю чужими Аля нього, але такими, що причепилися йому до язика.

$\mathrm{y}$ «Сватанні на Гончарівці» також віА самого початку акцентується розмежування між українською стихією, що домінує в мові абсолютної більшості персонажів - мешканців приміської слободи, і російськомовними авторськими ремарками. Але от з'явмяється Осип Скорик, відставний москаль, який висловлюється дикою сумішшю Авох спотворених мов: «...Усі нашаво брата поважають! Ні хрестини, ні свадьба у знакомих не буваїть, штоб без меня та абашлось. Правда і то, што уж ніхто так парядка не Аасть, как я. <...> Павидав-таки світу я на свайом віку! \. Його мовлення, цей народжений і виношений в імперсько-москальському моні лінгвістичний виродок, - предтеча майбутнього «харківського суржика», який за Квітчиних часів уже набирав силу на міських околицях. 
Петро Гулак-Артемовський, молодший сучасник Квітки, на відміну віА нього не був корінним харків'янином. Народився на Черкащині, у тодішній Київській губерніі, у сім'ї священника - вихідця з відомого козацько-старшинського роду. Його зв'язки з Харківським університетом були значно тіснішими, ніж Квітчині. Вступивши до університету 1817 року «вольнослушателем», він через порівняно короткий час став магістром, ад’юнктом, екстраординарним та ординарним професором, потім деканом словесного факультету, а 1821 року ректором університету й залишався на цій посаді до 1849-го. Головним напрямком викладацької діяльності Гулака-Артемовського була російська історія, також він читав мекції з російської словесності, естетики, польської мови, яку знав із дитинства (мати походила з польського шияхетського роду Артемовських), із порівняльного аналізу слов'янських мов. Українського компонента - окремо взятого - у колі педагогічних і наукових занять Гулака-Артемовського не було. Тимчасом у його мітературній творчості, у поезії та перекладах українська мова превалює абсолютно, у своїх байках і віршованих притчах він продовжив закладену І. Котляревським традицію творчого освоєння засобів національного низового бароко, бурлеску та травестії, увів до української мітератури новий для неї жанр романтичної балади. Новаторськими були перекцади Гулака-Артемовського на українську мову європейської класики (Горацій, Гете, Міцкевич). 3 Міцкевичем Гулак-Артемовський познайомився восени 1825 р. в Харкові, що, ймовірно, дало імпульс до написання «малоросійської балади» «ТварАовський», надрукованої за підписом «Г.» в московському «Вестнике Европы» (1827, № 6) з передмовою редактора журналу М. Каченовського. Ця балада, перша спроба фавстіани в українській мітературі, являє собою інтерпретацію містично-гумористичної балади Міцкевича «Пані Твардовська», витриману в стилі, характерному аля української народно-сміхової традиції. Ао цієї традиції належать і байки Гулака-Артемовського, зокрема хрестоматійна байка-казка «Пан та Собака».

Написані російською мовою мітературно-художні твори скмадають невелику порівняно з українськими і, головно, не зіставну з ними щодо художнього рівня частину спадщини письменника.

Чи усвідомлював Гулак-Артемовський незіставність російськомовної частини свого доробку з українськомовною? Виглядає, що він принаймні відчував із цього приводу певний душевний дискомфорт. 1827 року в мисті до В. Анастасевича Гулак-Артемовський кається з приводу свого «гріха» - невиконання планів створити «Словарь малороссийский», про який мріє «во сне и наяву», і даці висловлює свої міркування про Аолю рідної мови. Тут чітко виявицася хиткість, Авоїстість мовної (і не тільки) авторової позиції. 
Мысль, - пише Гулак-Артемовський, - что, может быть, близко уже время, когАа не только признаки малороссийских обычаев и старины будут изглажены навеки, но и самый язык сольётся в огромный поток величественного, вцадычествующего великорусского слова, и не оставит, быть может, по себе ниже тёмных следов своего существования, наводит на меня такую хандру, что иногда приходят минуты, в которые я решился бы отказаться от обольстительных надежд моего тесного честолюбия и удаАился в мирную кущу простодушного полянина - ловить последние звуки с каждым Анём умирающего родного языка [6, 132-133].

Пізніше, 1882 року, харківський історик А. Шиманов писав у журналі «Киевская старина»:

Воспоминания харьковцев о нравственной физиономии П. П[етрови]ча Авоятся; почти несомненно, что какое-то глубокое раздвоение скрывалось в душевном складе покойника. Гулак-Артемовский, видимо, был одним человеком pro domo sua и Аругим pro foro, при том с Аетами этот «Аругой человек» видимо осилил первого и поА конец, может быть, остался уже главным хозяином...» (цит. за: [26]).

Мовний чинник виступає маркером такого роздвоєння. Вочевидь, саме це мав на увазі Шевченко, закидаючи Гулакові-Артемовському, що він свою рідну мову, «хоть і чув [у колисці од матері], так забув, бо в пани постригся» $[41,208]$.

Інакший випадок харківського пограниччя - творча та й наукова спадщина Ізмаїла Срезневського. Його «думка» «Корній Овара» своїм задумом, мовою, стилем корелює з баладою Гулака-Артемовського «Твардовський» - це така ж сама спроба створити «українську версію» фавстівської теми в бурлескно-сміховій манері, в дусі «Енеїди» Котмяревського (у Срезневського зразком Аля творчого опрацювання був «Громобой» Жуковського).

«Корній Овара» є однією з небагатьох спроб Срезневського українською; росіянин за походженням, він був у махому віці вивезений із Ярославля до Харкова, де його батько викладав в університеті риторику, поетику та слов'янські мови. 3 Харковом пов'язані дитячі, студентські роки Срезневського-молодшого, ранній період його наукової та творчої діяльності. Срезневський опанував українську мову, високо поціновував

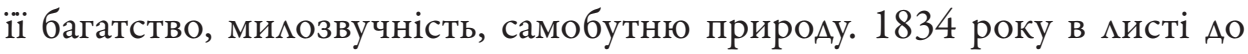
I. Снєгірьова, відомому ще як стаття «ПогляА на пам’ятки української народної словесності», він підкреслював, що нині вже немає потреби Аоводити, що «язык украинский (“ими как угодно называть другим: мамороссийский”) есть язык, а не наречие - русского или польского, как Аоказываци некоторые...» $[33,124]$.

При цьому свої праці харківського періоду про українську мову, фольклор, етнографію, історію, літературу Срезневський писав російською. Такі, наприклаА, як одна з ранніх його статей «Мысли и заме- 
чания», згадуваний щойно мист Ао I. Снєгірьова, також «Отрывки из записок о старце Григории Сковороде» та біографічне оповідання про Сковороду «Майор, майор!», післямова й пояснювальний словник Ао публікації в «Украинском сборнике» (кн. 1, 2, 1838, 1841) п’єс Котляревського «Наталка Полтавка» та «Москаць-чарівник». Такі передмова й коментарі Срезневського до збірника «Запорожская старина».

Срезневський був російським мітератором, котрий добре знав українську мову й залишив кілька українськомовних творів, дослідникомславістом; у його різноманітному спектрі наукових інтересів і занять праці з проблематики української історії, фолькмору, етнографії посідами не надто велике за обсягом, але важливе за значенням місце. Важливе

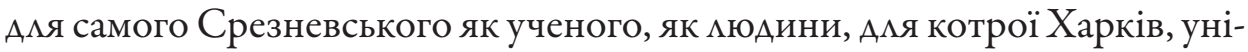
верситет, Слобожанщина, Україна стали частиною його життєвої долі. Значущість для цієї долі їі української складової не ставить піА сумнів той факт, що пізніше Срезневський відійшов од української тематики, скорегував деякі свої погляди, зокрема на українську мову, на слобожанську ідентичність, на проблему козацького самоуправління.

В університеті навколо Срезневського скцався гурток таких, як

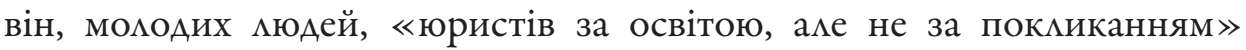
(В. Срезневський), мітераторів, котрі пов'язували свою творчість із українською народнопісенною та історичною традицією - брати О. та Ф. Євецькі, I. Росковшенко, О. Шпигоцький. У 30-ті роки заявмяє про себе Аруга романтична хвимя - $\Lambda$. Боровиковський, А. Метминський, М. Костомаров, М. Петренко, О. Корсун, С. Писаревський, В. Забіла. За підтримки Квітки-Основ'яненка та Гулака-Артемовського утворюється група поетів, яка ввійшла в історію української $і$ ітератури як Харківська школа романтиків.

Школа виникла в конкретних історичних і соціокультурних обставинах слобожанського пограниччя як інтелектуальне, духовне дитя Харківського університету й позначена була специфічними рисами цього пограниччя. ОАна, і то, певно, головна, з таких рис пов'язана з мовою.

В «Украинском альманахе», виданому 1831 року I. Срезневським і його товаришем по «ефіко-політичному» відАіленню І. Росковшенком (майбутнім головним московським цензором, таємним радником), три чверті публікацій - російськомовні, зокрема твори обох видавців. Таке співвідношення було характерним для харківських періодичних видань того часу, що позиціонували себе як українські. В «Украинском Вестнике», першому в Україні мітературно-художньому, науковому та громаАсько-політичному щомісячному журнаці (1816-1819), Арукувалися українські твори (тут, приміром, уперше побачима світ байка Гулака-Артемовського «Пан та Собака»), проте за своїм обсягом вони незіставні 3 корпусом російськомовних публікацій. Те саме стосується таких ви- 
Аань, як «Украинский журнац», «Харьковский Аемокрит», «Южный русский сборник». У 40-х роках у Харкові вийшли два українських ацьманахи - «Сніп» і «Молодик», у Петербурзі - зібраний Є. Гребінкою ацьманах-антологія «Аастовка» (Аив.: [3; 12; 21; 27]).

Щодо «Украинского альманаха», то його українська частина скмадалася з кількох народних пісень і дум, двох віршів $\Lambda$. Боровиковського та О. Шпигоцького й іще Авох перекладів останнього (один із них, уривок із пушкінської «Полтави», - це перший перекцад Пушкіна українською мовою). Ще Ава переклади Шпигоцького були російськомовними, як і всі його подальші перекладацькі роботи, а також дві поетичні спроби в жанрі романсу. Останні, «Малороссийская мелодия» та «Мамороссийский романс», примітні поєАнанням російськомовних назв із українським текстом — отака віршована «мікромодель» міжмовного та міжкультурного пограниччя.

Щось подібне спостерігаємо в $\Lambda$. Боровиковського, у його «малоросійських баладах», написаних російською, однак на мегко впізнаваному українському матеріаці - історичному («Смерть Пушкаря») або пісенному («Аве Аоли», «Кузнец», « Аихо»). Інший варіант - погранична модель зі «зворотнім» упізнаванням: «Маруся», переспів «Светланы» Жуковського (з перейменуванням героїні), «Ава ворони (3 Пушкіна)», перелицьований пушкінський вірш «Ворон к ворону метит», i «Подражаніє Горацію» з ознаками українського мандшафту.

Та головне, завдяки чому Боровиковський посів помітне місце в українській мітературі, - це вірші й балади, написані українською, в річищі національної Аірико-романтичної, пісенної та барочної традицій. Такі, наприклад, балади «Чарівниця», (в їі основу покмадено пісню

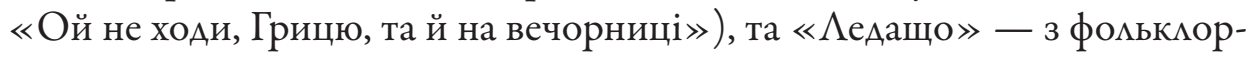
ним мотивом продажу козаком душі чортові.

Яскравою постаттю на тодішньому харківському культурному виАноколі був Микола Костомаров, постаттю, співмірною зі Срезневським за своїм місцем і значенням на харківському культурному пограниччі. Проте не за «мовною біографією», вона в Костомарова інакша. Хоч Острогозький повіт Воронезької губерніі, батьківщина Костомарова, історично був близький до Слобожанщини і значну частину населення губернії становими етнічні українці, проте Аля Костомарова, який приіхав 1833 року до Харкова і вступив на історико-філологічний факультет університету, українська мова була, за його визнанням, незнайомою. Ситуація, однак, змінилася швидко, і то кардинацьно: глибокому, органічному освоєнню Костомаровим української мови сприяло зближення його з представниками Харківської школи романтиків, захоплення фолькцором, етнографією, інтерес до історії козацтва. Важлива роль у цьому процесі належаца Срезневському. «Я став часто відвідувати його, 
і дім його зробився улюбленим місцем відпочинку та обміну думками», - згадує Костомаров в автобіографії [1, 351]. М. Сумцов, посилаючись на ці слова, додає, у своєму переказі, ще одне зізнання: «...I[змаї ] $\mathrm{I}[$ ванович] сильно сприяв розвиткові в ньому прагнення до вивчення малоруської народності. 3 його допомогою Костомаров став вивчати ма^оруську мову, мало йому знайому, та мацоруські повісті Квітки» (Аив. у: $[24,93])$. Усе це спонукало до творчості, й у цей період у Харкові народжується український письменник Єремія Галка; під цим псевдонімом Костомаров пише та видає українською мовою збірку віршів «Українські балади» та «Вітка», історичні твори - драму «Сава Чалий» і трагедію «Переяславська ніч». Наприкінці 40-х років у Київському університеті, куди його запросив М. Максимович на посаду професора російської історії, Костомаров увіходить до складу таємного слов'янота українофільського Кирицо-Мефодіївського братства, пише програмну Аля товариства «Книгу буття українського народу»; наслідком усього цього був арешт, Петропавлівська фортеця, заслання до Саратова. У 60-ті роки, очолюючи кафедру російської історії в Петербурзькому університеті, Костомаров і далі бере участь в українському національному русі, разом із П. Кулішем і В. Білозерським він створює петербурзьку українську «Громаду», активно співпрацює із журналом «Основа». В умовах прийняття 1863 р. Валуєвського циркуляра Костомаров виступає ініціатором збору коштів на користь видання книг наукового змісту українською мовою. У статті 1863 р. «Правы ми наши обвинители?», призначеній Аля газети «Голос», але забороненій цензурою, він писав, адресуючись, за його визнанням, до М. Каткова: «Вам не нравится маморусское наречие, на здоровье вам. А нам оно нравится. Что же с этим Аелать? Предоставьте нам говорить на этом “гадком грубом жаргоне”, не мешайте нам мюбить его <...>, а вы себе оставайтесь с мнением о его “ничтожестве и испорченности” » $[13,144]$.

Російський учений, фахівець із російської історії, Костомаров вкАючає в коло своїх наукових студій теми з минувшини України, пише капітальні праці про Богдана Хмельницького, про часи Руїни, Юрка Хмельницького, Павла Полуботка, Івана Мазепу. Єремія Галка належить минулому разом із харківським романтичним Sturm und Drang, але в історії залишається шляхетна постать російського вченого й українського письменника, постать, знакова Аля духовно-культурного пограниччя середини XIX ст.

У чому помягала значущість цього пограниччя як моменту в історії української Аітератури? В умовах тодішнього тотацьного імперського панування воно виявилося - хоч і як це, на перший погляА, парадоксацьно - реацьним і реалістичним Аля конкретної історичної ситуації чинником (точніше - одним із чинників) утвердження цією мітературою 
своєї національної ідентичності, становлення ії як однієї із самобутніх і самостійних європейських мітератур. Процес віАбувався в ситуації коекзистенційного переплетіння різних, часом суперечливих, тенденцій, роздікення та інтеграції, фронтирного протистояння і творчої взаємодії національних традицій, ментальних особливостей, незрідка застарілих стереотипів і пересудів. Усе це набирало нетривіальних, «симбіозних» форм, скмадався феномен, який можна означити поняттям «етнокультурне пограниччя». Хтось із його преАставників виявмяв живий інтерес Ао чужого, сприймаючи його як гіАне уваги й поваги інакще, а іноді робцячи його своїм, або майже свӧ̈м. Інші, зберігаючи пієтет до чужого й віААаючи йому данину, а часом навіть залишаючись, непомітно Аля себе, у його обіймах, прагнули вийти - і виходили - у просторінь свого.

Якщо перейти віА загальних міркувань до мітературної конкретики, то слід відзначити той факт, що прикмади звернення українських письменників XIX ст. Ао російської та інших мов знаходимо не тільки в західній (Галичина, Буковина) або східній (Слобожанщина, Харків) пограничних етнокультурних зонах. Полтавець Котляревський, із чиєю «Енеїдою» пов'язуємо початок нової української мітератури, відомий також як автор російськомовних творів, зокрема, «ОАы Сафо». Євген Гребінка, також полтавець, свій перший вірш («Рогдаев пир») надрукував російською мовою в харківському «Украинском ацьманахе», потім уславився українськими байками та «маморосійськими» приказками, які стали хрестоматійними; за петербурзьких часів Гребінка написав низку російськомовних романів і текст нині всесвітньо відомого романсу «Очи чёрные, очи страстные». «Петербуржець» і «казахстанець» Шевченко залишив кілька віршованих творів російською мовою та цімий корпус російськомовних повістей. Згадаймо піА цим оглядом також Квітку-Основ'яненка, Гулака-Артемовського, харківських романтиків, іще П. Куліша, Максимовича, Костомарова, Бодянського, О. Стороженка. У галицькому пограничному сегменті знаходимо польсько- та німецькомовні тексти в I. Франка, німецькомовні - в Ольги Кобимянської та О.-Ю. ФеАьковича. Або цікавий приклаА «зворотнього» порядку: етнічна росіянка Марія Вікінська, авторка російських романів і повістей, котра стала, під іменем Марко Вовчок, українською письменницею.

Емський акт, що його ОлексанАр II підписав 1876 року в німецькому місті БаА-Емс, закріпив і доповнив основні положення Валуєвського циркуляра. Українське мітературне поле на слобожанському пограниччі було, здавалося, зачищене з максимальною ретельністю. Так здавалося, та вийило інакше. Розвиткові національного письменства імперські утиски, звісно, завдавали шкоди, але зупинити його вони не могли, українське слово виявило високий рівень опірності й життєвої сили. 
1883 року в Харкові побачила світ збірка українських віршів «Ворскцо». Ї̈ автором був Яків Щоголів, останній із харківських романтиків, який тихо доживав свій вік у невеличкому дерев' яному будинку в Харкові на Коцарській вулиці. За кілька десятиліть перед тим, на самому початку 40-х років, гімназист Щоголів надрукував у « Иитературной газете» А. Краєвського елегію «Раздумье», а в «Отечественных записках» балаАу «Канари», присвячену герою війни за незалежність Греції адміралові Костянтину Канарісу; до того періоду належить іще кілька російськомовних елегій. Пізніше, вже студентом Харківського університету, Щоголів виступає в кількох випусках ацьманаху «Молодик», близького до шкоми харківських романтиків, у різних випусках ацьманаху публікуються то російські, то ранні українські вірші молодого поета. Після Аво- чи то трирічної перерви він на запрошення Амвросія Метлинського передає Аля «Южного русского сборника» кілька українських віршів, які, оАнак, із причин, нам достеменно не відомих, побачили світ Аише 1860 р., і то не в «Сборнике», а в петербурзькому альманасі П. Куліша «Хата». У наступні десятиліття Щоголів багато сил і часу відАає Аержавній службi, потім, вийшовши на демісію, він, пригнічений життєвими справами та родинними нещастями - смертю сина і старшої дочки, живе, за спогадами молодшої дочки, Є. Шаховської-Брабант, «тихо, спокійно, монотонно» [39]. Пише він у ці роки небагато, тепер мише українською.

Негучну, перейняту натурфілософськими мотивами, народнопісенними інтонаціями, релігійними настроями й метафізичною печацлю поезію Щоголева помітили й оцінили сучасники - прихильники і знавці; по-справжньому критика осмислика цього автора після його віАходу. Аруга - і остання - поетична книжка Щоголева, «С Аобожанщина», побачима світ 1898 року, коли шлях наймолодшого - й останнього - 3 поетів харківського романтичного кола завершився. У Аень, коли чорна валка з домовиною Щоголева рухалася харківськими вулицями на міський цвинтар, у книгарнях з'явимася його книжка в зеленій палітурці Богдан Аепкий порівнює іï із зеленою гілкою, заготовленою самим поетом на свою Аомовину $[19,18]$.

Ао метафори домовини вдається - в іншому контексті та з іншим значенням - також Микола Зеров у статті «Непривітаний співець». За його словами, Щоголів «доніс Ао кінця століття» погляди й настрої харківських романтиків, він - наче «живий пам'ятник на гробі давно минулої доби» $[11,66]$. Певно, це сказано занадто категорично. Завершення діяльності Харківської школи романтиків не було їі відходом у небуття. В останні десятиліття XIX століття в тому ж Харкові, на базі того ж університету й не без впливу ідей та прямої підтримки провіАних представників школи, Срезневського й Костомарова, склалася ії наукова «реінкарнація» - Харківська мінгвістична школа. 
Засновник і визнаний голова «Школи-2» Олександр Потебня був вихідцем із Полтавської губернії, гімназію закінчив у польському Радомі, але вся його наукова діяльність пов'язана з Харківським університетом і позначена печаткою харківського культурного та мовного пограниччя. Потебня ріс і формувався як учений в умовах російсько-української біАінгвальності й у своїх досліАженнях спирався на діалог цих двох мов; при цьому, однак, у праці «Мова і народність» негативно висловлювався про Авомовність, уважаючи, що вона «роздвоює коло Аумки», утруАнює «досягнення цілісності світоспоглядання». Сам він чудово знав українську мову, високо поціновував ії Аінгвістичний і художній потенціал (до речі, перекладав на українську «ОАіссею» Гомера, збереглися уривки). У кисті до чеського філолога-славіста Адольфа Патери віА 11 Аютого 1886 р. Потебня пригадує свої «уроки малоросійської» Аитячих Аіт, на хуторі бабусі, та підкреслює роль української мови у своєму формуванні як ученого: «Обставинами мого життя зумовцено те, що при наукових моїх заняттях вихідним пунктом моїм, іноді помітним, іноді не помітним Аля інших, була малоросійська мова та малоросійська народна словесність. Якби цей вихідний пункт і пов'язане з ним почуття не було мені дано та якби я виріс поза зв'язком із традицією, то, мені зАається, навряд чи я став би займатися наукою» $[23,93]$ (Аив.: [40]). Водночас усі свої наукові та філософські праці він пише російською, ба більше, українську мову називає «малоросійською говіркою», а поняттям «російська мова» означує сукупність схіАнослов' янських мов.

Щодо Аітературного процесу, то «непривітаний», за визначенням Зерова, Щоголів був усе-таки не «пам'ятником минумої доби», а раАше перехідною постаттю, котра означила спадкоємність духовно-національних інтенцій романтичної школи. Молодші сучасники та земляки Щоголева, слобожани-харківці - Павло Грабовський, Архип Тесленко, Іван Манжура - перші свої кроки в Аітературі робили, як і він, на культурному й мовному пограниччі: російськомовні вірші, публіцистичні та наукові статті, Аистування, переклади з російської кмасики. Подібно до Щоголева, вони із часом переходили - сливе виключно, або принаймні з абсолютною перевагою, — на українську.

Що ж відбувалося Аалі?

$\triangle а \Lambda і$ дискурс харківського етнокультурного пограниччя набуває принаймні на певний, і то чималий, відрізок часу - переривчастого і Араматичного характеру.

В умовах воєнних і революційних пертурбацій перших Авох десятиАіть XX ст. нормальний розвиток означених вище тенденцій порушується, починає домінувати стихія хаосу, на поверхню історичного процесу спливають випадкові, маргінальні, швиАкоплинні факти та явища, втрачають чіткість кордони, межі, а разом і помежів'я, перехідні форми поступаються 
місцем перед стрибкоподібними. Харків тих часів - perioн підвищеної соціальної турбулентності, життєвий простір, через який навпереміну, а то й водночас, із різних сторін накочуються хвилі різного забарвлення «жовто-сині» 3 південного заходу, «білі» з південного сходу, «червоні» з північного сходу. На цьому пограниччі, у цій божевільній круговерті народжувався, поставав інакший Харків. «Був Харків слобіА, хуторів і ремісників, — писав 1948 року Юрій Шерех (Ю. Шевельов). - Був Харків - провінційне купецьке місто несходимої і безвихідно-сірої російської імперіі. Тепер Хвицьовий проголошує третій Харків, символ українського урбанізму. ЗАибленої і м’ятежної України. <...> Третій Харків - Харків Хвильового і ВАП МТТЕ, Курбасового “Березомя”, виставок АРМУ в залях колишнього монастиря, непримиренно пацких диспутів у Будинку мітератури ім. Блакитного на Каплунівській, Курсів сходознавства, українського студентства <...> $>[42,479-480]$. Такий Харків стає центральним «персонажем» творів Хвильового, його друзів і колег (П. Тичина, М. Йогансен, I. Аніпровський, Т. Масенко, О. Копиленко), в українській мітературі скцадається особливий «харківський текст» (Аив.: [37]).

Так було.

Проте було не так просто. Союзна влада не мала наміру миритися із цими «збоченнями», і за справу береться, засукавши рукава, «ГПУ». Починаються репресіі, які після самогубства Хвимьового 13 травня 1933 року набирають величезних масштабів. Українське культурне віАродження входить в історію як «розстріляне».

Не просто все було й з інших, об'єктивних, причин. Ю. Шевельов, говорячи про «українізовані» харківські заводи, треба визнати, віААає Аанину ілюзіям своїх старших колег-земляків 20-х років. Насправді завоАи не квапилися з українізацією, робітники, попри те, що більшість (хоча не абсолютну) в їхньому середовищі становили етнічні українці, були чималою мірою російськомовними, у кожному разі, не виявцяли великої націонацьної активності. Поготів це стосується значної частки міського населення, тих, хто належав до інших національних груп - росіян, євреїв, вірмен, поляків, греків, також - що з історичних причин було традиційним Аля Харкова - російськомовних (такими вони себе позиціонували, насправді ж були «суржикомовними») українців. Ця мінгво- та етнокультурна ситуація відображена у знаменитій комедії Миколи Куліша, центрацьний персонаж якої, харківський обиватель Мина Мазайло, за підтримки «тьоті Моті з Курська», міняє своє, на його думку, не Ауже благозвучне українське прізвище на російське - Мазєнін. Шевельов також навряд чи має рацію і тоді, коли створення в Харкові російського театру та російськомовної газети ставить в один ряд із репресивними акціями влади, спрямованими проти націонацьного культурного відродження. Російський театр і газета самі собою - природні атрибути 
етнокультурного пограниччя, яким був Харків, інша річ, які ідеологічні цілі переслідувала вцада; перетворення українського «Березоля» $з$ театру європейського гатунку та рівня, яким він був піА керівництвом $\Lambda$ еся Курбаса, на провінційне етнографічне видовище було більш серйозною загрозою Аля української культури, ніж відкриття російського театру.

У наступні десятиліття ситуація на пограниччі «стабілізується», час віА часу застійний «мир-та-спокій» порушується ідеологічними кампаніями та каАровими чистками в культурній сфері, боротьбою то з «провокаційними націоналістичними» закликами на зразок «любіть Україну!», то з космополітизмом, після чого все повертається на свої місця. Харківське етнокультурне пограниччя деструктурується, втрачає свою осібність і сенс. Так, у місті, як пам'ятаємо, функціонують український і російський театри, виходять російськомовні газета й альманах, а водночас газета й журнац українською, видавництво випускає книжки обома мовами. Ао місцевої письменницької організації входять українські й російські мітератори, творчість Авох преАставників обох груп (I. Муратов і В. Аобровольський) симетрично відзначено стацінськими преміями. Усі ідеологічні норми дотримано, «віковічну дружбу» двох народів і культур продемонстровано.

А от пограниччя як духовного феномену і як креативного чинника немає, це, властиво, уже не пограниччя - живе, з пульсуванням суперечностей та взаємовпливів, а конгломерат явищ, які існують в одному просторі одночасно й паралельно, сукупність формальних ознак. Неформацьне українсько-російське мовне пограниччя функціонує на «низовому» рівні міського життя — як прикмета повсякденного спілкування, побутової практики, як маркер культурних запитів, звичок, смаків різних груп населення. I «трендом» у пограничній ситуації доводиться визнати превацювання російськомовної стихії у сфері повсякденного культурного споживання. Це превалювання мише почасти скмадалося внаслідок об' єктивних соціацьно-економічних причин, а великою мірою піА впливом цілеспрямованих заходів керівних органів партії та радянської влади - заходів пропагандистських, організаційних, каАрових, адміністративних. Ао характеристики цієї харківської ситуації (втім, не мише харківської, але наразі мовиться саме про неї) повною мірою пасує запропонований О. Сухомлиновим стосовно східних регіонів України, передовсім до Харкова та Аонбасу, термін «тигель культур» - як означення «особливого типу культурного пограниччя» $[35,149]$. Польська філологиня Гелена Красовська, авторка передмови до монографії О. Сухомлинова, щоправда, завважує, і то слушно, що цей термін «потребує більш докладного науково-теоретичного обгрунтування» $[15,8]$.

Зміни в суспільному житті оприявнюються вже у 50-ті роки, у наступному десятилітті вони стають реацьним фактом духовно-культур- 
ного життя України, однією з визначацьних прикмет доби. Шістдесятництво, зародившись на порубіжжі десятиліть як культурницький рух, швиАко переросло в значущий ідеологічний чинник, в опозиційну силу, в Аисидентство. Воно охопило всі сфери культури, та особливий резонанс викликало в $і$ тературному середовищі, бо зачепимо таку дражливу сферу, як проблеми національної мови. Виступи В. Стуса, І. Світличного, I. Азюби, Є. Сверстюка, Аіни Костенко, А. Павцичка, М. Руденка, В. Симоненка, М. Вінграновського, I. Арача, авторитетних мітераторів старшої генерації - Б. Антоненка-Аавидовича і Г. Кочура сигналізувами про перехід на новий етап націонацьного культурного відродження, спадкоємний щодо попереднього, розстріляного, та не забутого. На Аінгво- та етнокультурному пограниччі означуються зрушення в «український бік»; з'явилися нові, принципово важливі акценти, корегувалися уявлення про цінності й пріоритети. Ао того ж, хоча процес у цілому був загацьнонаціональним, однак у регіонах він проходив із різною мірою охоплення та інтенсивності. У Харкові цей рух не був надто бурхливим; щоправда, створений 1956 року український мітературний журнац «Прапор» Арукував твори шістдесятників, статті про Аітературу 20-х років, про репресованих за сталінщини письменників; український театр шукав і зчаста знаходив шляхи до творчого продовження та розвитку курбасівських традицій, однак загальна конфігурація культурного пограниччя, співвідношення його компонентів, передовсім, мовних, тут суттю зацишацися такими, як раніше.

Залишалися такими вони до 90-х років і початку Авохтисячних, коли в нових суспільно-політичних умовах український вектор, якщо говорити в загацьному плані, став домінантним в українській мітературі. Така тенденція характерна і дһя тодішньої ситуації на харківському пограниччі, вона $є$ очевидною, тож немає потреби зупинятися на подробицях. Крім, мабуть, одного цікавого й принципово важливого моменту, який стосується загалом української «пограничної» проблематики в сучасних умовах.

«...Сьогодні прийшка мода і потреба згадувати і помічати братів наших “менших” - російськомовних письменників, які мешкають в Україні», — пише харківський критик Ігор Бондар-Терещенко (Аив.: [5]). Тут не дуже вдало вжите слово «мода», а особливо зовсім уже недоречні єсенінські «брати наші “менші” » - добре відомо, хто́, згідно з офіціозною імперською ієрархією, вважався впродовж століть «старшим братом», а кого поблажливо йменуваци «молодшим». Але примітним є інше факт визнання досвідченим критиком, який перебуває не зовні, а в самій гущавині мітературного життя регіону, і критиком украӥнським, украӥнсъкомовним, - визнання того, що в сьогоднішній Україні, конкретно - у Харкові, місце російськомовного письменника в загацьнонаціонацьному 
Аітературному процесі (а не в мітичному «русском мире») визначається насамперед - i тільки - естетичним рівнем і змістовою вагою його, цього письменника, творчості. Зі 3MI, з мітературної преси відомо, як останніми роками зростає кількість російськомовних творів, що їх виАають харківські видавництва.

Важливим $є$ те, що найбільш цікаві твори російськомовних авторів, котрі живуть (або жики до недавнього часу) в Україні, дають критиці приводи та, головно, підстави Аля широких - як позитивного, так і критичного плану, - зіставцень та анацізу в контексті української мітератури. Важливим $є$ те, що виникає та реалізується на практиці потреба зближення різномовних і «різнорегіональних» письменників України, відбувається їхнє зближення не на словах, а у творчому процесі, наприклаА, у колективному проєкті - романі «АНК», який об’єАнав мітераторів Харкова, Аонбасу, Галичини та Волині. Важливим є те, що російськомовний журнац «Союз писателей», який виходить у Харкові ось уже Авадцять років, поширюється не тільки в межах слобожанськоАонбаського пограниччя, а й у Києві та Аьвові, його можна побачити на полицях книгарень у Німеччині, Ітахії, Аанії, США, Ізраїлі, де живуть російські письменники - колишні харківці. Засновник і співредактор «(Союза писателей» Андрій Краснящих був ініціатором та одним з авторів публікації у Facebook (2 березня 2014 р.) заяви харківських ро-

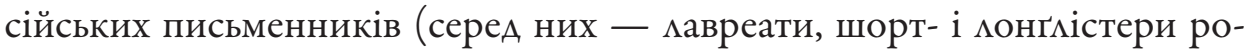
сійських премій), котрі відкидають твердження московських 3MI про «утиск прав росіян в Україні». «Мы, русские писатели Харькова, - наголошено в заяві, - хотим, чтобы были услышаны и наши голоса: мы свободно, на работе и вне её, общаемся на русском языке, и с украинскими комлегами тоже...».

Аонбаський сегмент

Наважуся заторкнути й предражливу тему українсько-російського пограниччя, конкретно на Аонеччині й Ауганщині. Можу говорити лише про літературний аспект щзвого пограниччя. Чи багато ми знаємо про тривале співжиття в иих краях украӥнського і російського літературного слова? Чи досліджена матерія цього співжиття, його історія і динаміка? А за цим - i політичні, державні проблеми, і соціопсихологічні, і етнокультурні, і етичні...

Іван, Азюба

(Аітературна Україна, 25 жовтня 2017р.).

...Чому піА поширеною через Фейсбук 2 березня 2014 р. заявою харківських російських письменників, які рішуче відкидають тверАження прокремлівських 3МІ про «утиск прав росіян в Україні», відсутній підпис Володимира Рафєєнка, автора роману «Аолгота дней » ААже за своїм сенсом, патосом, за іАейною та морацьною авторовою позицією 
цей твір стовідсотково суголосний із цією заявою, тож поза будь-яким сумнівом підпис міг би там бути; або скажімо так: якби ми його там побачими, то не знайшии б у цьому нічого дивного. Ситуацію можна пояснити Аише суто формальною обставиною - Рафєєнко не є харківським письменником, він письменник Аонбаський, хоча цей роман, написаний російською мовою, побачив світ - факт, що його навряд чи можна сприйняти інакше, як знаковий, - саме в Харкові [30] (Того ж року у Аьвові з'явився український перекмаА [29]).

Володимир Рафєєнко - уродженець і корінний мешканець Аонецька. У травні 2014 р. він був із тими, хто бив на сполох на Азвіниці Свято-Преображенського кафедрального собору в Аонецьку в рамцях акції за мирний Аонбас, тоді ще зоставалася надія. А в мипні, коли в місто ввійшли озброєні цюди (словами Рафєєнка, «бурятские танкистыотпускники»), він із родиною - так само, як і деякі його колеги-земляки, 一 виїхав до Києва.

...Обостримось ощущение, - розповідає письменник про перші місяці в статусі «переселенця», — что меня не стало, убили по дороге в Киев, но Господь почему-то решил дать мне ещё пожить. Я умер, но почему-то живу. Меня нет, но я есть. Я хочу Аомой, но дома нет. Это Алимось с полгода. А потом жизнь и книга, которую я начац писать, стами мечить [16].

Метафора смерті-відродження в цьому визнанні - ремінісценція до передфінацьних епізодів роману «Аолгота дней». Три центральних

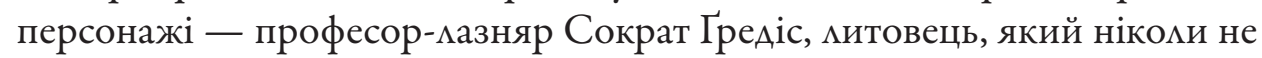
бував у $\Lambda$ итві, ще гульвіса марний, поет зі знаковим російським прізвищем Вересаєв і ще $\Lambda$ іза-Елеонора, віддалено схожа на Гетеву Маргариту і водночас на Маргариту булгаковську. Ці персонажі проходять крізь своєрідний метафізичний тунель між смертю «от рук матрёшек цвета хаки» і «переселенським» життям.

«Аолгота Аней» - роман зі складною структурою та гнучкою, рухмивою системою засобів поетики. У ньому Ава різних текстових шари, що відбивають два ракурси в підході до зображуваного. ОАин шар, соціально-побутовий, реалістичний, подекуди не позбавлений натуралістичних рис, скмадають «казки»-новели Вересаєва - фрагменти побаченого й пережитого в місті Z, відкинутого війною в якесь страхітливе іншобутmя, насичені, ба перенасичені болем «натюрморты войны», зібрання моральних каліцтв, брехні, мюдських оман і самооман, трагічних і трагікомічних ситуацій. Аругий шар тексту - метафоричний, ігровий, із переходами у фантасмагорію, через яку відкриваються сенси та поетика замкненого простору - метафізичної Аазні піА назвою «П’ятий Рим», своєрідної мікромодені деформованого війною міського простору. Тут 
відчутно резонують містичні сни Сковороди та гоголівські петербурзькі видива й примари, відгомони магічного реалізму Маркеса та позірної вірогіАності Фолкнерової Йкнапатофи, а ще казкових мотивів (у «доросмих» версіях та інтерпретаціях) «старого доброго Андерсена». Синтез контрастних поетичних стихій, перетини часопросторових ракурсів вирішальний чинник реалізації авторового задуму роману як трагічної донбаської містерії в Україні XXI століття.

Майже одночасно з «Аолготой Аней» побачив світ іще один «Аонбаський » роман, цього разу вкраїнський, - «Інтернат» Сергія Жадана, уродженця Ауганщини й доволі давнього вже харків'янина [8]. Роман такою ж мірою актуацьний, але - інакший. Цю інакшість «Інтернату» було анонсовано - опосередковано, у підтексті - ще до його з'яви, у відгуку Жадана на український перекмад роману Рафєєнка [9].

Жадан називає твір земляка-донбасівця «надзвичайно важливим» і «необхідним», однак і «суперечливим», і цю суперечливість означено вже в заголовку рецензії - «Містика проти реальності». «Символічні та містичні події», «босхівські картини», «перетікання реацьного в нереальне», «гра», «реальність перетворюється на метафори» - фіксуючи ці особливості поетики роману «Аолгота Аней», Жадан визнає, що це, «на відміну віА більшості написаного про цю війну — <... таки хуАожня Аітература, не репортажна, не щоденникова й не журналістська». I тут-таки завважує (щоправда, із застереженням «можииво»), що ця художність «заважає», бо «досі скмадно сприймати події на Сході саме

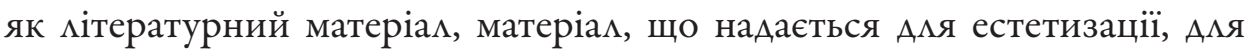
гри, для цитування й стилізації». Тут опосередковано, але Аосить чітко вияв ена декларація автора про поетику власного роману, який - ми тепер це знаємо - на той час завершувався або, радше, вже був написаний.

Що можна сказати під цим оглядом про «Інтернат»?

Аекларацію значною мірою реалізовано в тексті, націленість автора на пріоритет поетики «реацьного» перед поетикою «нереацьного» тут очевидна.

Жахииві картини охопленої війною донбаської території: напівзруйнований будинок, вулиця, що прострілюється наскрізь, інтернатський підвац-схованка - повсякденність, перейнята атмосферою страху та занепаду. Гранична вірогідність, що межує з натурацістичністю, виворіт війни, біль війни, бруд, моральний занепад шокують. Шок піАсимюють стриманість авторового тону, підкреслено проста інтонація оповіді, за якими вгадується прагнення уникнути мітературної «естетизації» зображуваного, «містики», будь-якої метафоризації, залишивши все це романові Рафєєнка.

На щастя, «Інтернат» написано не схильним Ао теоретизувань рецензентом, а митцем, котрий відчуває і знає, що війна, крім емпіричного, 
реального виміру, має вимір четвертий, прихований, ірреацьний, і що самою $и$ еме емірикою, нехай і найвірогіднішою, не обійтися. Свідомо чи стихійно, за велінням художнього чуття і таланту, письменник увіходить у багатовимірний простір нетривіацьних засобів осягнення реальності, ii прихованої символіки та метафорики, ракурсів і змамів, які вислизають із поля поверхового зору. Тоді підвац інтернату перетворюється на метафізичний замкнений простір, а нафарбовані обличчя інтернатських дівчаток, котрі тут ховаються, постають метафорою недитячого миця війни. Тоді роуд-сюжет поїзАки героя в інтернат за племінником фронтовою дорогою між «укропами» $\mathrm{i}$ «олорадами», на розбитому «Опелі» з прив'язаною нагорі домовиною, набуває символічного значення як ШАях до істини й до самого себе через війну, ШАях, успішного

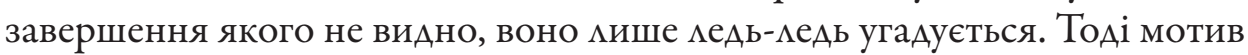
бездомних, голодних міських собак, епізод із цуценям на руках підмітка, озброєного бітою («Виросте - всіх порве») сприймаються як метафори загального зАичавіння, деформації дитячих душ.

Ці компоненти поетики «Інтернату» корелюють з особливостями індивідуальної манери, характерної для роману Рафєєнка «Аолгота Аней». Пограниччя між Авома творами розширюється, еволюціонує віА мовного Ао образно-поетичного, мотиваційного, семантичного.

Примітною є близькість позицій обох авторів в акцентуації проблеми соціацьно-морацьного вибору особистості, яка опиницася в кризових умовах, і в потрактуванні цієї проблеми через мотив провини та віАповідацьності. 3 тими, хто ініціював трагедію заради своїх особистих або кланових інтересів, хто їм протегує та допомагає, і з тими, хто приїхав «рятувати» цей край, подібно до Івана Івановича з роману Рафєєнка з ними все ясно. Але проблема провини глибша. У романі Жадана Ніна, Аиректорка інтернату, каже: «...Не тіште себе ілюзіями, відповідати буАуть усі. I найгірше буде тим, хто відповідати не звик». «Усі» - тобто й ті, «хто взагалі ні при чому», як пояснює капеман біженцям зі зруйнованого ворогами міста у вірші Жадана «-Звідки ти, чорна валко, пташина зграє?»: «Потрібно було уважніше читати книги пророків. / Потрібно було оминати пекемьні діри». Провина нерозуміння, невміння та небажання розуміти, перебування під гіпнозом застарілих ідеологічних стереотипів або найновіших пропагандистських телевізійних кліше; таким у Рафєєнка постає Пашка, котрий усе «разцичац мутновато, как через грязное стекцо. Ну и, в конце концов, записался, на войну против Правого сектора и, соответственно, за Гоголя, Гагарина...».

I $є$ особлива провина тих, хто не відчуває своєї провини, бо не звик за що-небудь відповідати. Такий в «Інтернаті» Паша, який, перебуваючи в самому вирі війни, намагається зацишитися в межах зони вцасного спокою, намагається, річ ясна, марно. 
Тут зробімо відступ, утім, у рамцях теми.

Мотив провини - парадигмамьний і один із найгостріших у книжці молодого донецького письменника та блогера Станіслава Асєєва «В ізомяції»; тут зібрані статті та репортажі, або, як зазначено в підзаголовку, «Аописи з Аонбасу» [2]. Ці «дописи» автор, перебуваючи на окупованій території, упродовж Авох із половиною років, аж до арешту «МГБ $A$ НР» й ув'язнення [звільнений у грудні 2019 року в рамцях обміну] Арукував під псевдо «Васін» на сайті «Радіо Свобода», у газеті «Азеркало тижня» та в журналі «Український тиждень». Мотив провини, протинаючи текстовий простір, не завершується гармонійною каденці$є ю$; так само й означена ним проблема морального вибору, провини та відповідальності ^юдини в сучасному «донбаському контексті» не дістає розв'язання в зібраних докупи дописах, як - принаймні поки що — й у жорстокій життєвій практиці. Та книжку Асєєва вирізняє із заганьного пубАіцистично-пропагандистського потоку передусім те, що пошук такого якщо не розв'язання, то бодай зрозуміння проблеми, ведеться зсередини, а не ззовні, він ініціюється і живиться реаліями підокупаційного повсякдення, у яких проживає автор і які він переживає. В Асєєва проблема провини постає в координатах ментальної та ідейно-моральної тріади Чуже-Інакше-Своє. Автор книжки, як і ії герой-оповідач, належить до української, за його виразом, «пасіонарної меншості»; іï преАставники, зберігаючи свою ідентичність і вірність національній ідеї, не полишають донбаську землю, бо вважають ії українською. У його свідомості й відчуттях фронтирне Чуже втрачає чіткі контури, на передній план виступає скмадне, болюче пограниччя-сплетіння Чужого з Інакшим й обох - зі Своїм. Уявний «цинік»-оповідач звертається до «своєї держави» [стаття «Иист циніка своїй державі»] із закликом не сприймати «Аюдей з українським громадянством всередині та вмурованих у потворний мандшафт “ $A$ HP” » як «не таких» українців [2, 202, 291]. «Незрозуміння» цих Аюдей, ширше - «незрозуміння» Аонбасу як пограничного феномену, природи і причин його інакшості, регіональної, межової ідентичності Homo Donbasus - то, гадає Асєєв, велика помилка і провина.

Так, він суб'єктивний у своїх судженнях, тези його книжки, завважує доброзичлива рецензентка, — «це тільки одна з багатьох “лінз”, крізь які можна дивитися на Аонбас» [10]; щодо грунтовності аналізу, виваженості й переконливості аргументації вона вочевидь поступається згаданим у рецензії працям зарубіжних та українських науковців $[17 ; 18 ; 34 ; 43 ; 44]$. Та книжка Асєєва й не претендує на порівняння з ними, поготів на змагання; іiі наратив розгортається у зовсім іншій площині - у площині живих вражень, Аюдського болю, національної образи, емоційних реакцій, часом не керованих, не обмежених кимось установценими нормами чи стерео- 
типами масової свідомості. Можна говорити про суб’єктивність оцінок і висновків автора, а можна - про потенціал вірогідності й щирості оповіді, які збуджують думку, спонукають ї̈ до постави нешаблонних запитань і пошуку адекватних відповідей. Це дорого вартує.

Повернімося безпосередньо до нашого дискурсу.

Спільність тем, сенсів, потрактувань, оцінок, схожість - за збереження відмінностей - деяких аспектів поетичних систем та образних засобів додає поняттю пограниччя нові моменти, котрі, проте, не розмивають його, і поготів не скасовують. Чинником стабільності пограниччя як поняття/концепту виступає наявність Авох мовних стихій, у випадку Жадана і Рафєєнка - української і російської. За всіх умов обидві зберігають свою первісну природу, мова залишається одним із найважливіших критеріїв національної ідентичності. Що не виключає можливості виникнення - під упливом мінливих зовнішніх обставин, тенденцій «зустрічного руху» Авох мовних стихій, моментів їхньої взаємодії, часом активної, аж до спроб подолання роз'єАнувацьних Аіній, навіть зміни мовних векторів. Так, Рафєєнко в одному з інтерв'ю розповідає, що свій новий роман, «дистанційований від війни», але пов'язаний із життям «переселенця зі Сходу», він пише українською, хоча не певен у «мовній адекватності» твору, бо відчуває, що його українська поки ще далека віА Аосконацості ${ }^{1 .}$. У цьому конкретному життєвому та творчому епізоді відбиті породжені війною надзвичайно скцадні, часом парадоксальні, а незрідка й драматичні процеси на донбаському етнокультурному, зокрема мовному, пограниччі. 3 одного боку, украй загострюються, набувають фронтирного, навіть агресивного характеру позиції представників обох сторін, що об'єктивно веде до перетворення пограниччя в зону відчуження. 3 Аругого - частіше виявлення толерантного, конструктивного підходу. Коли Сергій Жадан, український письменник, який знає силу й

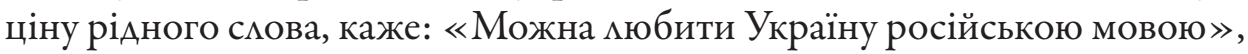
за цим стоїть не готовість до компромісу зі зневажливо-хамською тезою «какая разница», а тверезе усвідомлення неоднозначних реалій війни, іiі парадоксів, духовно-морацьних уроків і наслідків.

Я <..> знаю багатьох Аюдей, які є добровольцями, волонтерами, громадськими активістами, але на четвертому році війни вони не відмовилися від своєї російської. Так, вони намагаються <...> переходити [на українську], себто дмя них це не абсолютно чужа мова, але не переходять. Чому? Я можу їх зрозуміти: у тебе нема середовища, у тебе немає практики... Це насправді не так просто [22].

\footnotetext{
${ }^{1}$ Це роман «Мондегрін. Пісні про смерть і мюбов», [31], у ньому відтворено — значною мірою в постмодерністичному ключі - процес «самоукраїнізації» героя-оповіАача, його повернення до рідної мови предків, колись ними забутої.
} 
Нещодавно побачило світ знакове з погляду «пограничної» проблематики видання - антологія «Порода»; до неї ввійшли твори українських і російських письменників другої половини XX — початку XXI ст., чиї біографії та (або) творчості пов'язані з Аонбасом [29]. Антологія ста-

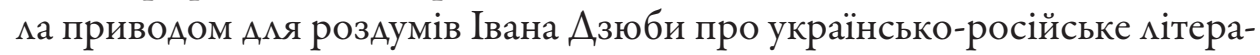
турне пограниччя цього регіону. Його вступне слово містить не тільки огляд і характеристики вкАючених до антології текстів, а й методологічні міркування, спрямовані на подальше дослідження теми, на «перевіАкриття Аонбасу» (назва передмови), на розробку різних аспектів проблеми українсько-російського пограниччя як важливого структуро- та сенсотвірного чинника культури України. Аумки Азюби авторитетні й важливі як свідчення Аітератора, котрий знає проблему не із чуток; він народився на донбаській землі, закінчив свого часу Сталінський педагогічний інститут (нині Аонецький національний університет ім. Василя Стуса, функціонує у Вінниці).

Назва книжки не позбавлена провокативного відтінку, бо в мовленнєвій практиці поняття «порода» пов'язується зазвичай з уявленням про некорисні віАходи - або в прагматичному аспекті, стосовно гірничодобувної галузі, або в аспекті образному, метафоричному. Укцадачі антології акцентують у ії назві інше - гру сенсів; «порода» тут - це сховані в глибинних шарах суспільства і Аюдської натури, поки що не виявлені й не видобуті цінні елементи й водночас це сформований особливими умовами Аюдський тип високого гатунку, «донбаський характер».

Ао антології ввійшли поетичні, прозові та Араматургічні твори Аеякі в уривках - українських і російських авторів старшої та середньої генерацій, а також ті, чиє духовне і творче становлення випало вже на роки доби незалежності, зокрема, на останні десять-п'ятнадцять років; присутність в антології представників цього мітературного призову I. Азюба в передмові до книжки відзначає як одну зі суттевих особливостей видання, називаючи, утім, іще два значущих моменти. Це «виклик уявленню про Аонеччину (принаймні кітературну) як заповідник совєтщини та “совковості"» і це акцент «на принципово важливому факті нормального (чи змагального?) співіснування (в деякі періоди) на Аонеччині українського й російського Аітературного Слова та можливій перспективі такого співіснування в майбутньому, якщо воно, це спікьне майбутнє, таки буде...» $[7,6]$. У ракурсі проблематики мінгвокумьтурного пограниччя ця, третя, особливість антології постає головною.

Biдомо, що кількісні показники не надто багато вирішують в оцінці явищ і процесів художньої творчості, та все ж варто звернути увагу на той — як видається, прикметний - факт, що в антології українські та російські письменники представлені в рівних, або сливе рівних, частках. Це може бути витцумачено Авояко - як, з одного боку, свідчення того, що 
українське слово не розчинилося в російськомовній донбаській стихії, з Аругого - як підтвердження висловленої автором цієї статті стосовно сучасного Харкова завваги, що характерна дмя останніх десятикіть природна інтенсифікація українськомовного «стрижня» в загацьнонаціональному цітературному потоці не супроводжується зниженням творчого тонусу російської мітератури в Україні, радше навпаки, є підстави віАзначити його підвищення. ВАастиво, це Ава аспекти єАиного процесу гармонізації складного ментально-творчого феномену Чуже-ІнакшеСвоє на етнокультурному пограниччі при збереженні його (пограниччя) внутрішньої діалектики як інноваційного чинника.

Із цим процесом пов'язана ще одна вельми суттєва особливість антології. Зрозумілим і закономірним є той факт, що в іiі тематичній, Аоволі різноманітній, гамі, яка охоплює проблематику другої половини минулого століття та початку нинішнього, - що в цій гамі превалюють трагічні події останніх років на сході України, мотиви війни, страждань і загибелі мюдей, біженства, підміни та спотворення цінностей, розколу Аюдських спільнот, руйнації дружніх зв'язків і навіть родин, Ауховного й морального зубожіння. Примітним $є$ те, шо в художньому відображенні та осягненні цього болючого проблемно-тематичного шару своє місце знаходять донбаські письменники обох мовних груп. Вище це було показано на прикладі творів С. Жадана та В. Рафєєнка; обоє представлені в антології, перший - великою добіркою поезій, які тематично, емоційно та естетично коремюють 3 «нтернатом», Аругий - уривком із роману «Аолгота Аней». За принципом близькості ідейно-моральних, гуманістичних позицій авторів і за очевидної, зчаста вельми суттєвої, ба сутнісної, несхожості естетики та поетики, можна вичценувати також інші творчі «пари». НаприклаА, оповідання «Виклик» Олега Зав'язкіна, манері якого властива химерна суміш вірогідних деталей в описі буднів прифронтової «швидкої допомоги» із забарвленою іронією фантастикою, - і спокійно-роздумлива, дуже особистісна російська проза Світмани Заготової. Або знаковий Аля поезії Аюбові Якимчук, переселенки з Ауганська, трагіко-експресіоністичний вірш «розкладання» - саме так, із малої Аітери, грою звуків, розривами слів і відсутністю розділових

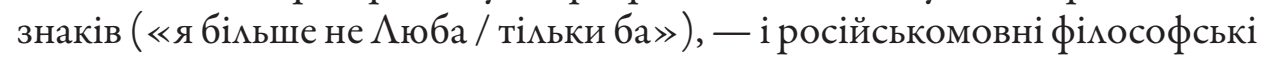
поетичні етюди Ігоря Козцовського, ученого-релігієзнавця. Або гротескна фантастика прозового фрагмента Станіслава Федорчука «Столиця совків і Юрій» і актуацьні біблійні алюзї в поетичному циклі Ярослава Мінкіна про «город, которого вот-вот не станет».

Які висновки можна зробити зі щойно наведених прикладів?

Упорядники антології формулюють свій заздалегідь, іще до публікації текстів. Назву видання супроводжено підзаголовком: «Антологія українських письменників Аонбасу». Тобто належність усіх представле- 
них в антології авторів до української нітератури означено за географічним і тематичним принципами, незалежно віА мови їхніх творів. Такий - простий, як двічі по Ава, - піАхіА не є новим Аля мітературно-критичної практики в Україні; деяким учасникам дискусій, що точилися впроАовж останніх десятиліть, він видається привабливим і плідним, бо нібито розширює та збагачує простір української Аітератури. Варто, однак, звернути увагу на те, що I. Азюба в передмові до антології формулює суть проблеми принципово інакше: «...Українське Слово і російське Слово в устах чесних та відповідацьних синів нашої країни звучать в унісон, коли йдеться про АюАську гідність і право на життя у свободі. В Україні» $[7,19]$. Звісна річ, поняття «унісон» не універсальне Аля характеристики етнокультурного пограниччя; існує багато ситуативних варіантів, стосовно яких доцільні інші означення, приміром, «фронтир», «розділення», «протистояння», «конфмікт». Але щодо розгяянутого конкретного випадку - сучасного Аонбаського Аітературного пограниччя - запропоноване Азюбою поняття «унісон» сприймається як коректне і точне.

\section{МITEPATУРA}

1. Автобиография Н. И. Костомарова. Москва: Задруга, 1922. 440 с.

2. Асєєв С. В ізоляції: Тексти, фото; передм. М. Арач, С. Рахманіна, А. Крапивенка; ілюстр. С. Захарова. Київ: Аюта справа, 2018. 208 с.

3. Багалей А. Опыт истории Харьковского университета (по неизданным материалам). Т. 2 (1815-1835 гг.). Харьков: Тип. и мит. М. Зимьберберга, 1904.1136 с.

4. Багалей А. УАаление профессора И. Б. ШаАа из Харьковского университета. Харьков, Зимьберберг, 1899, 147 с.

5. Бондар-Терещенко I. Українська і російська проза сьогодення: дві моделі «імперськості». URL: https://tsn.ua/blogi/themes/books/ukrayinska-i-rosiyska-proza-sogodennyadvi-modeli-imperskogo-buttya-892438.html

6. Гулак-Артемовський П. Твори / Упоряд. Б. Аеркач. Київ: Видавництво художної Аітератури «Аніпро», $1978.160 \mathrm{c}$.

7. Азюба I. Перевідкриття Аонеччини // Порода. Антологія українських письменників Аонбасу. УпоряА. В. Бімявського та М. Григорова. [Київ:] Видавництво «Аегенда», 2017. C. 6-19.

8. Жадан C. Інтернат. Чернівці, Meridian Czernowitz, 2017.336 c.

9. Жадан C. Містика проти реальності. URL: https://starylev.com.ua/club/article/mistykaproty-realnosti

10 Зарембо К. Станіслав Асєєв (Васін). В ізомяції. Аописи про Аонбас // Критика. 2019. Березень. URL: https://m.krytyka.com/ua/reviews/v-izolyatsiyi-dopysy-pro-donbas

11. Зеров M. Ао Ажерел. Історико-літературні та критичні статті. Харківське видавництво, 1943.272 с.

12. Киселёв $В$. Имперская словесность и славянский митературный регионализм: случай украинской журналистики начала XIX в. // Русин. 2015. № 4 (42). С. 66-85.

13. Костомаров $H$. Правы ми наши обвинители? (По вопросу об издании книг научного содержания на южнорусском языке) // Український історичний журнал. 1990. № 7. C. $140-146$.

14. Кравченко B. Харьков/Харків: столица пограничья. Вильнюс: Европейский гуманитарный университет, 2010.358 c.

15. Красовська Г. Переднє слово // Сухомлинов О. Культурні пограниччя: новий погляА на стару проблему. Аонецьк: Юго-Восток, 2008. С. 4 -8. 
16. Кригель М. Роман с Аонецком. Посмертные приключения звонаря. Как писатель Р. Уехал из города Z. в страну U., по дороге умер и написал роман. URL: https://focus.ua/ long/350379/

17. Кульчицький С., Якубова А. Триста років самотності: український Аонбас у пошуках смислів і Батьківщини. Київ: КАіо, 2016.719 с.

18. Куромія Гіроакі. Свобода і терор у Аонбасі: українсько-російське прикордоння, 18701990-ті роки. Пер. з англ.: Г. Кьорян, В. Агеєв; Передм. Г. Немирі. Київ: ВиА-во Соломії Павличко «Основи», 2002.510 с.

19. Аепкий Б. Яків Щоголів // Щоголів Я. Вибір творів. 3 портретом автора та вступною статтею Богдана Аепкого. Видавництво «Українське слово» в Берліні, [1924]. С. 5-19.

20. Маслійчук В. Провінція на перехресті культур. Аослідження з історії СлобіАської України XVII-XIX століть. Харків, Харківський приватний музей міської садиби, 2007. $400 \mathrm{c}$.

21. Михайлин I. Історія української журналістики XIX століття. ПіАручник. Київ: Центр навчальної нітератури, 2003. 720 с.

22. «Можна мюбити Україну російською мовою»: інтерв’ із Жаданом про Аонбас та «Інтернат». URL: https://maximum.fm/mozhna-lyubiti-ukrayinu-rosijskoyu-movoyuintervyu-iz-zhadanom-pro-donbas-ta-internat_n127757

23. Олександр Опанасович Потебня. Ювілейний збірник до 125-річчя з дня народження. Київ: Видавництво Академії наук УРСР, 1962. 110 с.

24. Памяти Измаила Ивановича Срезневского. Книга I. Петроград, Типография Императорской Академии Наук, 1916. VIII, 421 с.

25. Пінчук Ю. Заборонена стаття М. І. Костомарова // Украйнський історичний журнам. 1990. № 7. C. $137-140$.

26. Полішук B. Із перших класиків. Ао 225-річчя від Аня народження Петра Гулака-Артемовського // Аень. 2015. 31 січня. URL: https://day.kyiv.ua/uk/article/ukrayinaincognita/iz-pershyh-klasykiv

27. Полякова Ю. Русские литературно-художественные журналы Харькова XIX-XX веков (попытка перечисления) // Союз писателей (журнал, Харків). 2005. № 1 (6). С. 29-47.

28. Порода. Антологія українських письменників Аонбасу. УпоряА. В. Білявського та М. Григорова. Передмова I. Азюби. Київ: Видавництво « Аегенда», 2017. 383 с.

29. Рафєєнко В. Аовгі часи. Переклад Маріанни Кіяновської. Мева, 2017.272 с.

30. Рафеенко B. Аолгота Аней. Харьков: Издательство «Ранок»; «Фабула», 2017. 304 с. (Серия «Современная проза Украины»).

31. Рафєєнко В. Мондегрін. Пісні про смерть і любов. Чернівці: Meridian Czernowitz, 2019. $192 \mathrm{c.}$

32. Роммель К. А., Фон. Спогади про моє життя та мій час. Пер. з нім. В. Маслійчук, Н. Оніщенко. Харків, Майдан, 2001.206 с.

33. Срезневский И. ВзгляА на памятники украинской народной словесности. Письмо к профессору И. М. Снегиреву // Ученые записки Императорского Московского университета. Год второй. Часть шестая. Москва: В университетской типографии, 1834. C. $134-150$.

34. Студенна-Скруква М. Український Аонбас. Обличчя регіональної ідентичності. Пер. з пол. А. Бондар; наук. реА. перекмаду В. Кабуладзе. Київ: Аабораторія законодавчих ініціатив, 2014. 409 с.

35. Сухомлинов О. Культурні пограниччя: новий погмяА на стару проблему. Аонецьк, ЮгоВосток, 2008. 212 c.

36. Ушкалов А. Аітература галицька, слобідська та інші: принцип коекзистенції // Історії мітератури. Центр гуманітарних досліАжень $\Lambda$ ьвівського національного університету

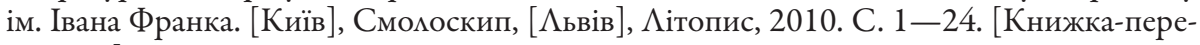
вертень].

37. Цимбал Я. «Харківський текст» 1920-х років: обірвана спроба // Иітературознавчі обрії. Праці молодих учених. Вип.18. Київ: Інститут Аітератури НАНУ], 2010. C. $54-61$. 
38. [Чернов А.] Вступна інтермедія // Иітературний ярмарок. 1929. Кн. 4 (134). Березень. C. $4-10$.

39. Шаховська-Брабант Є., кн. Біографія й спомини про поета Я. Щоголева // Аіно (Аьвів). 1923. 15 червня.

40. Шевельов Ю. Олександер Потебня і українське питання // Потебня О. Мова. Національність. Аенаціоналізація: ст. і фрагм. / упорядкування і вступна стаття Ю. Шевельова. Українська Вікьна Академія Наук у США. Нью-Йорк [б.в.]., 1992. С. 7-48.

41. Шевченко T. [Передмова до нездійсненого видання «Кобзаря»] // Шевченко Т. Повне зібр. творів: У 12 томах Т. 5. Київ: Наукова Аумка, 2003. С. 207-208.

42. Шерех Ю. Четвертий Харків // Шерех Ю. Пороги і запоріжжя. Аітература. Мистецтво. ІАеологіі. Харків: Фоліо, 1998. Т. I. С. 478-492.

43. Siegelbaum, L. H., Walkowitz, D. J. Workers of the Donbass Speak: Survival and Identity in the New Ukraine, 1989-1992. New York: State University of New York Press, 1995. 254 p.

44. Wilson A. The Donbas between Ukraine and Russia. The Use of History in Political Disputes // Journal of Contemporary History. 1995 Vol. 30, No. 2 (Apr.). P. 265-289.

Отримано 13 квітня 2020 p.

\section{REFERENCES}

1. Avtobiografiya N. I. Kostomarova (1922). Moscow: Zadruga. [in Russian]

2. Asieiev, S. (2018). Vizoliatsii: Teksty, foto. Kyiv: Liuta sprava. [in Ukrainian]

3. Bagalej, D. (1904). Opyt istorii Khar'kovskogo universiteta (po neizdannym materialam). T. 2 (1815-1835 gg.). (Vol. 1-2; Vol. 2). Kharkiv: Tip. i lit. M. Zil'berberga. [in Russian]

4. Bagalej, D. (1899). Udalenie professora I. B. Shada iz Khar'kovskogo universiteta. Kharkiv: Zil'berberg. [in Russian]

5. Bondar-Tereshchenko, I. (2017, March 7). Ukrainska i rosiiska proza sohodennia: dvi modeli "imperskosti". Retrieved from https://tsn.ua/blogi/themes/books/ukrayinska-i-rosiyskaproza-sogodennya-dvi-modeli-imperskogo-buttya-892438.html. [in Ukrainian]

6. Derkach, B. (Ed.), Hulak-Artemovskyi, P. (1978). Tvory. Kyiv: Vydavnytstvo khudozhnoi literatury "Dnipro". [in Ukrainian]

7. Dziuba, I. (2017). Perevidkryttia Donechchyny. In Biliavskyi, V. \& Hryhoriv, M. (Ed.). Poroda. Antolobiia ukrainskykh pysmennykiv Donbasu, pp. 6-19. Kyiv: Vydavnytstvo "Lehenda". [in Ukrainian]

8. Zhadan, S. (2017). Internat. Chernivtsi: Meridian Czernowitz. [in Ukrainian]

9. Zhadan, S. (2017, August 28). Mistyka proty realnosti. Retrieved from URL: https:// starylev.com.ua/club/article/mistyka-proty-realnosti [in Ukrainian]

10. Zarembo, K. (2019, March). Stanislav Asieiev (Vasin). V izoliatsii. Dopysy pro Donbas. Krytyka. Retrieved from https://m.krytyka.com/ua/reviews/v-izolyatsiyi-dopysy-prodonbas [in Ukrainian]

11. Zerov, M. (1943). Do dzherel. Istoryko-literaturni ta krytychni statti. Kharkiv; Lviv: Kharkivske vydavnytstvo. [in Ukrainian]

12. Kiselyov, V. (2015). Imperskaya slovesnost' i slavyanskij literaturnyj regionalizm: sluchaj ukrainskoj zhurnalistiki nachala XIX v. Rusin, 4 (42), pp. 66-85. [in Russian]

13. Kostomarov, N. (1990). Pravy li nashi obviniteli? (Po voprosu ob izdanii knig nauchnogo soderzhaniya na yuzhnorusskom yazyke). Ukrainskyi istorychnyi zhurnal, 7, pp. 140-146. [in Russian]

14. Kravchenko, V. (2010). Khar'kov/Kharkiv: stolica Pogranichya. Vil'nyus: Evropejskij gumanitarnyi universitet. [in Russian]

15. Krasovska, H. (2008). Perednie slovo. In Sukhomlynov, O. Kulturni pohranychchia: novyi pohliad na staru problemu, pp. 4-8. Donetsk: Yuho-Vostok. [in Ukrainian]

16. Krigel', M. Roman s Doneckom. Posmertnye priklyucheniya zvonarya. Kak pisatel' R. uekhal iz goroda Z. v stranu U., po doroge umer i napisal roman. Retrieved from https://focus.ua/ long/350379/ [in Russian] 
17. Kulchytskyi, S. \& Yakubova, L. (2016). Trysta rokiv samotnosti: ukrainskyi Donbas u poshukakh smysliv i Batkivshchyny. Kyiv: Klio. [in Ukrainian]

18. Kuromiia, H. (2002). Svoboda i teror u Donbasi: ukrainsko-rosiiske prykordonnia, 1870— 1990-i roky. (H. Korian \& V. Aheiev, Trans.). Kyiv: Vydavnytstvo Solomii Pavlychko "Osnovy". [in Ukrainian]

19. Lepkyi, B. (1924). Yakiv Shchoholiv. In Shchoholiv, Ya. Vybir tvoriv. Z portretom avtora ta vstupnoiu statteiu Bohdana Lepkoho, pp. 5-19. Berlin: Vydavnytstvo "Ukrainske slovo" v Berlini. [in Ukrainian]

20. Masliichuk, V. (2007). Provintsiia na perekhresti kultur. Doslidzhennia z istorii Slobidskoi Ukrainy XVII-XIX stolit. Kharkiv: Kharkivskyi pryvatnyi muzei miskoi sadyby. [in Ukrainian]

21. Mykhailyn, I. (2003). Istoriia ukrainskoi zhurnalistyky XIX stolittia. Pidruchnyk. Kyiv: Tsentr navchalnoi literatury. [in Ukrainian]

22. "Mozhna liubyty Ukrainu rosiiskoiu movoiu": interviu iz Zhadanom pro Donbas ta "Internat" (2017, September 22). Retrieved from https://maximum.fm/mozhna-lyubiti-ukrayinurosijskoyu-movoyu-intervyu-iz-zhadanom-pro-donbas-ta-internat_n127757 [in Ukrainian]

23. Oleksandr Opanasovych Potebnia. Yuvileinyi zbirnyk do 125-richchia $z$ dnia narodzhennia. (1962). Kyiv: Vydavnytstvo Akademii nauk URSR. [in Ukrainian]

24. Pamyati Izmaila Ivanovicha Sreznevskogo. Kniga I. (1916). Petrograd: Tipografiya Imperatorskoj Akademii Nauk. [in Russian]

25. Pinchuk, Yu. (1990). Zaboronena stattia M. I. Kostomarova. Ukrainskyi istorychnyi zhurnal, 7, pp. 137-140. [in Ukrainian]

26. Polishchuk, V. (2015, January 31). Iz pershykh klasykiv. Do 225-richchia vid dnia narodzhennia Petra Hulaka-Artemovskoho. Den. Retrieved from https://day.kyiv.ua/uk/ article/ukrayina-incognita/iz-pershyh-klasykiv [in Ukrainian]

27. Polyakova, Yu. (2005). Russkie literaturno-khudozhestvennye zhurnaly Khar'kova XIXXX vekov (popytka perechisleniya). @oyuz pisatelej, 1 (6), pp. 29-47. [in Russian]

28. Biliavskyi, V. \& Hryhoriv, M. (Ed.). (2017). Poroda. Antolohiia ukrainskykh pysmennykiv Donbasu. Kyiv: Vydavnytstvo "Lehenda". [in Ukrainian]

29. Rafieienko, V. (2017). Dovhi chasy. (M. Kiianovska, Trans.). Lviv: Vydavnytstvo Staroho Leva. [in Ukrainian]

30. Rafeenko, V. (2017). Dolgota dnej. Khar'kov: Izdatel'stvo "Ranok"; "Fabula”. [in Russian]

31. Rafieienko, V. (2019). Mondegrin. Pisni pro smert i liubov. Chernivtsi: Meridian Czernowitz. [in Ukrainian]

32. Rommel K. D., von. (2001). Spohady pro moie zhyttia ta mii chas. (V. Masliichuk \& N. Onishchenko, Trans.). Kharkiv: Maidan. [in Ukrainian]

33. Sreznevs'kij, I. (1834). Vzglyad na pamyatniki ukrainskoj narodnoj slovesnosti. Pis'mo k professoru I. M. Snegirevu. Uchenye zapiski Impertorskogo Moskovskogo universiteta. God vtoroj. Chast'shestaya, pp. 134-150. Moscow: V universitetsokj tipografii. [in Russian]

34. Kebuladze, V. (Ed.) Studenna-Skrukva, M. (2014). Ukrainskyi Donbas. Oblychchia regionalnoi identychnosti (A. Bondar, Trans.). Kyiv: Laboratoriia zakonodavchykh initsiatyv. [in Ukrainian]

35. Sukhomlynov, O. (2008). Kulturni pohranychchia: novyi pohliad na staru problemu. Donetsk: Yuho-Vostok. [in Ukrainian]

36. Ushkalov, L. (2010). Literatura halytska, slobidska ta inshi: pryntsyp koekzystentsii. In Istorii literatury, pp. 1-24. Kyiv: Smoloskyp; Lviv: Litopys. [in Ukrainian]

37. Tsymbal, Ya. (2010). "Kharkivskyi tekst" 1920-kh rokiv: obirvana sproba. Literaturoznavchi obrii. Pratsi molodykh uchenykh, 18, pp. 54-61. Kyiv: Instytut literatury NANU. [in Ukrainian]

38. [Chernov, L.] (1929, March). Vstupna intermediia. Literaturnyi yarmarok, 4 (134), pp. 4-10. [in Ukrainian]

39. Shakhovska-Brabant, Ye., kn. (1923, June 15). Biohrafiia y spomyny pro poeta Ya. Shchoholeva. Dilo. [in Ukrainian] 
40. Shevelov, Yu. (1992). Oleksander Potebnia i ukrainske pytannia In Shevelov, Yu. (Ed.) Potebnia, O. Mova. Natsionalnist. Denatsionalizatsiia: statti i fragmenty, pp. 7-48. New York: Ukrainska Vilna Akademiia Nauk u SShA. [in Ukrainian]

41. Shevchenko, T. (2003). [Peredmova do nezdiisnenoho vydannia "Kobzaria"]. In Shevchenko, T. Povne zibrannia tvoriv (Vol. 1-12; Vol. 5), pp. 207-208. Kyiv: Naukova dumka. [in Ukrainian]

42. Sherekh, Yu. (1998). Chetvertyi Kharkiv. In Sherekh, Yu. Porohy i zaporizhzhia. Literatura. Mystetstvo. Ideolohii (Vol. 1-3; Vol. 1), pp. 478-492. Kharkiv: Folio. [in Ukrainian]

43. Siegelbaum, L. H. \& Walkowitz, D. J. (1995). Workers of the Donbass Speak: Survival and Identity in the New Ukraine, 1989-1992. New York: State University of New York Press.

44. Wilson, A. (1995). The Donbas between Ukraine and Russia. The Use of History in Political Disputes. Journal of Contemporary History, 30, 2 (Apr.), pp. 265-289.

Received 13 April 2020

Yurii Barabash, doctor of philology, professor

A. M. Gorky Institute of World Literature

25a Povarskaya st., Moscow, Russian Federation, 121069

e-mail: barabash.yuri@gmail.com

ORCID: https://orcid.org/0000-0002-8938-9408

\section{ALIEN-DIFFERENT-ONE'S OWN. NORTH-EAST ETHNIC AND LINGUAL CULTURAL FRONTIER OF UKRAINE (KHARKIV, DONBAS)}

In the article, which continues the discourse of ethnocultural frontier, the attention is focused on the facts and problems referring to the Ukrainian-Russian cultural frontier of Eastern Ukraine. Polyethnic character of the society initially, since the mid 17th century, determined the presence of two culture-forming components in the region, namely Ukrainian and Russian ones, the dynamics of their correlation in various historical periods, the motion of transitive forms and ambivalent conditions. (The Jewish element acquired the essential function in the ethnocultural system of the region later, mainly in the 20th century.) In the frames of the so-called Kharkiv school of romantics a unique linguocultural situation, not deprived of paradoxicality, was formed, in which Ukrainian-Russian bilingualism objectively performed as one of the factors shaping the development of the Ukrainian literature. From this perspective, the article conducts the diachronic analysis of the main stages of the literary process in Ukrainian Slobozhanshchyna, mainly in its center, Kharkiv. The researcher focuses on such issues and phenomena as the role and significance of Kharkiv University founded in 1805; Kharkiv periodicals and collections in the Russian and Ukrainian languages; the activity of such influential figures as $\mathrm{H}$. Skovoroda, $\mathrm{H}$. Kvitka-Osnovianenko, P.Hulak-Artemovskyi, I. Sreznevskyi, M. Kostomarov, O. Potebnia, etc.; contradictory and dramatic literary life in Kharkiv of the national cultural Renaissance epoch in the 1920s and early 1930s ('Executed Renaissance') and during the subsequent periods.

The 'Donbas segment' of the eastern ethnocultural frontier, with its history being much shorter than the Kharkiv one though also abundant with contradictions, is considered in the synchronic aspect, in comparative contrast of the different writers' fates and creative phenomena, including the background of the modern dramatic situation in the region.

Keywords: frontier, polyethnic character, identity, linguocultural situation, bilingualism, Kharkiv school of romantics, Executed Renaissance, Donbas segment. 